\title{
Stres psikososial kronis dengan kejadian hipertensi pada pekerja lapangan pabrik gula PT. Indolampung Perkasa
}

\author{
Rahma Elliya', Marliyana² ${ }^{2}$ Yulianto ${ }^{3 *}$ \\ 1Program Studi IImu Keperawatan Universitas Malahayati Bandar Lampung. \\ Email: bundaauliyusri@yahoo.co.id \\ ${ }^{2}$ Akademi Keperawatan Baitul Hikmah Bandar Lampung. Email: marliyana.nafa@yahoo.com \\ 3Medical Clinic PT. Indolampung Perkasa Kabupaten Tulang Bawang. *Email: alhusam3012@gmail.com
}

\begin{abstract}
Chronic psychosocial stress and hypertension among sugar cane plantation workers in Lampung, Indonesia
\end{abstract}

Background: The background of this research is based on data obtained from the 2016 Tulang Bawang District Health Office; hypertension is one of the causes of death. In 2016 the number of deaths from hypertension in Tulang Bawang Regency was 34 cases. Based on the results of the pre-survey by researchers, it was known from 532 workers who went to the Medical Clinic at PT. Indolampung Perkasa diagnosed with hypertension as many as $168(31.57 \%)$ people.

Purpose: Knowing correlation between chronic psychosocial stress and hypertension among sugar cane plantation workers in Lampung Indonesia.

Methods: Type of study was quantitative, with cross sectional design. The populations of this study were all sugar cane plantation workers at PT. Indolampung Perkasa and sample of 229 respondents. Data collection was primary, directly to respondents by distributing questionnaires. Data analysis was chi square with OR 2.637.

Results: It was known from 229 respondents with hypertension, as many as $79(34.5 \%)$ respondents were hypertensive and as many as $150(65.5 \%)$ respondents were not hypertensive. Known from 229 respondents with stress, as many as $82(35.8 \%)$ respondents were stressed and as many as $147(64.2 \%)$ respondents were not stressed with (p-value 0.001 ; OR 2,637).

Conclusion: There were correlation between chronic psychosocial stress and hypertension among sugar cane plantation workers in Lampung Indonesia.

\section{Keywords: Chronic psychosocial stress; Hypertension; Sugar cane plantation workers}

Pendahuluan: Berdasarkan data yang diperoleh dari Dinas Kesehatan Kabupaten Tulang Bawang tahun 2016, penyakit hipertensi menjadi salah satu penyebab kematian. Pada tahun 2016 jumlah kematian akibat hipertensi di Kabupaten Tulang Bawang sebanyak 34 kasus. Berdasarkan hasil pra survey yang dilakukan peneliti diketahui dari 532 orang pekerja yang berobat ke Medical Clinic PT. Indolampung Perkasa dengan diagnosa hipertensi sebanyak $168(31,57 \%)$ orang.

Tujuan: Diketahui hubungan stres psikososial kronis dengan kejadian hipertensi pada pekerja lapangan.

Metode: Jenis penelitian kuantitatif, dengan desain / rancangan cross sectional. Populasi sebanyak 532, sampel sebanyak 229 responden. Pengumpulan data secara primer, langsung kepada responden dengan membagikan kuesioner. Analisis data secara univariat (distribusi frekuensi) dan bivariat (chi square) dengan nilai OR 2,637.

Hasil: Diketahui dari 229 responden dengan hipertensi, sebanyak $79(34,5 \%)$ responden yang hipertensi dan sebanyak $150(65,5 \%)$ responden yang tidak hipertensi. Diketahui dari 229 responden dengan stres psikososial kronis, sebanyak $82(35,8 \%)$ responden yang stres psikososial kronis dan sebanyak $147(64,2 \%)$ responden yang tidak stres psikososial kronis dengan ( $p$-value 0,001 ; OR 2,637).

Simpulan: Ada hubungan stres psikososial kronis dengan kejadian hipertensi pada pekerja lapangan.

Kata Kunci : Stres psikososial kronis; Hipertensi; Pekerja Lapangan 
Stres psikososial kronis dengan kejadian hipertensi pada pekerja lapangan pabrik gula PT. Indolampung Perkasa

\section{PENDAHULUAN}

Penyakit tidak menular (PTM) merupakan penyakit kronis yang tidak ditularkan dari orang ke orang. PTM diantaranya penyakit jantung, hipertensi, stroke, kanker, diabetes, dan Penyakit Paru Obstruktif Kronis (PPOK). PTM merupakan hampir $70 \%$ penyebab kematian di dunia. Prevalensi penduduk dengan tekanan darah tinggi secara nasional sebesar 30,9\%. Prevalensi tekanan darah tinggi pada perempuan $(32,9 \%)$ lebih tinggi dibanding dengan lakilaki $(28,7 \%)$. Prevalensi di perkotaan sedikit lebih tinggi $(31,7 \%)$ dibandingkan dengan perdesaan $(30,2 \%)$. Prevalensi semakin meningkat seiring dengan pertambahan umur (Kementerian Kesehatan Republik Indonesia, 2017).

Hipertensi terjadi ketika tekanan darah di pembuluh darah meningkat secara kronis. Hal tersebut dapat terjadi karena jantung bekerja lebih keras memompa darah untuk memenuhi kebutuhan oksigen dan nutrisi tubuh. Jika dibiarkan, penyakit ini dapat mengganggu fungsi organ-organ lain, terutama organ-organ vital seperti jantung dan ginjal (Kementerian Kesehatan Republik Indonesia, 2018). Meningkatnya kejadian hipertensi cenderung terjadi pada orang dengan faktor risiko, hipertensi mempunyai gejala umum yang di timbulkan seperti pusing, palpitasi, mudah lelah, impotensi, sakit kepala, rasa berat ditengkuk, sukar tidur, mata berkunang-kunang (Harrison, Wilson, \& Kasper, 2012).

Penyakit hipertensi menjadi salah satu penyebab kematian. Jumlah kematian akibat hipertensi sebanyak 34 kasus. Jika dilihat dari kunjungan ke pusat pelayanan kesehatan penyakit hipertensi menempati urutan pertama jumlah kunjungan terbanyak dengan total kunjungan kasus baru sebanyak 2081 kasus dan sebanyak 7438 kasus lama dengan prevalensi sebesar $20,3 \%$ berdasarkan total kunjungan ke fasilitas pelayanan kesehatan (Dinas Kesehatan Tulang Bawang , 2017).

Faktor risiko hipertensi lainnya umur, jenis kelamin, riwayat keluarga, genetik (faktor resiko yang tidak dapat diubah/dikontrol), kebiasaan merokok, konsumsi garam, konsumsi lemak jenuh, penggunaan jelantah, kebiasaan konsumsi minumminuman beralkohol, obesitas, kurang aktifitas fisik, stres, penggunaan estrogen (Kementrian Kesehatan Republik Indonesia, 2014). Stres dapat memicu timbulnya hipertensi melalui aktivasi sistem saraf simpatis yang mengakibatkan naiknya tekanan darah secara intermiten (tidak menentu) (Andria, 2013). Stress dapat merangsang timbulnya hormone adrenalin dan menicu janutng berdetak lebih kencang sehingga memicu peningktan tekana darah (Sari, 2017).

Hasil analisa 91 responden maka diperoleh bahwa responden yang mengalami stress sebanyak 77 orang, 14 orang lainnya tidak stres. Yang mengalami hipertensi berat 49 , hipertensi sedang 28, hipertensi ringan 14 orang, $p=0,029<$ $a=0,05$, berarti ada hubungan yang signifikan antara stress dengan kejadian hipertensi (Syavardie, 2015). Hasil penelitian lain menunjukkan sebagian besar responden memiliki tingkat stres sedang (38\%) dan menunjukkan hipertensi (56\%). Hasil uji chi square menunjukkan ada hubungan yang signifikan antara stres dengan kejadian hipertensi dengan nilai $p$ value $=0,000$ (Arifin, \& Weta, 2016).

Kejadian hipertensi di PT Indolampung Perkasa lebih tinggi jika dibandingkan dengan yang PT lain, dimana di tahun 2016 penyakit hipertensi sebanyak 437 orang, tahun 2017 sebesar 516 orang dan di tahun 2018 penyakit hipertensi menjadi penyakit nomor tiga tertinggi dengan jumlah kejadian sebesar 624 orang dibawah dari penyakit pernafasan dan pencernaan. Sedangkan di PT Sweet Indo Lampung dan PT Humas Jaya, diketahui hipertensi merupakan penyakit di peringkat enam dan tujuh.

\section{METODE PENELITIAN}

Jenis penelitian kuantitatif dengan rancangan penelitian analitik, pendekatan secara cross sectional. Penelitian dilaksanakan di PT. Indolampung Perkasa Kecamatan Gedung Meneng Kabupaten Tulang Bawang pada April Juni 2019. Populasi seluruh pegawai lapangan yang berjumlah 532 responden dengan sampel 229 responden. Teknik sampling secara purposive sampling.

Alat ukur/instrumen yang digunakan untuk mengukur hipertensi menggunakan spignomanometer digital. Sementara, mengetahui stres psikososial kronis dengan kuesioner DASS 14 pernyataan, dan analisis data menggunakan uji chi square.

Pengumpulan data dilakukan secara primer dengan mengukur hipertensi yang dilakukan

Rahma Elliya' Program Studi llmu Keperawatan Universitas Malahayati Bandar Lampung.

Email: bundaauliyusri@yahoo.co.id

Marliyana ${ }^{2}$ Akademi Keperawatan Baitul Hikmah Bandar Lampung. Email: marliyana.nafa@yahoo.com

Yulianto ${ }^{3}$ Medical Clinic PT. Indolampung Perkasa Kabupaten Tulang Bawang. *Email: alhusam3012@gmail.com 
Stres psikososial kronis dengan kejadian hipertensi pada pekerja lapangan pabrik gula PT. Indolampung Perkasa

langsung oleh peneliti kepada responden, dan untuk mengetahui stres psikososial kronis peneliti melakukan pengukuran langsung dengan mengisi kuesioner DASS sesuai dengan pengalaman responden. Selanjutnya, responden diminta untuk menjawab dengan cara memberi tanda silang $(X)$ pada salah satu kolom yang paling sesuai dengan pengalaman responden selama satu minggu terakhir.

\section{HASIL}

Tabel 1. Karakteristik Responden $\mathbf{N}=\mathbf{2 2 9}$

\begin{tabular}{lcc}
\hline \multicolumn{1}{c}{ Variabel } & Frekuensi (f) & Persentase (\%) \\
\hline Usia & 35 & 15,2 \\
20-35 tahun & 145 & 63,3 \\
$35-50$ tahun & 48 & 20,9 \\
$>50$ tahun & & \\
Jenis Kelamin & & \\
$\quad$ Perempuan & 47 & 20,5 \\
$\quad$ Laki - laki & 182 & 79,4 \\
Tingkat pendidikan & & \\
$\quad$ SMP & 12 & 5,2 \\
$\quad$ SMA & 160 & 69,8 \\
Sarjana & 57 & 24,8 \\
Hipertensi & & \\
Menderita & & 34,5 \\
Tidak menderita & 79 & 65,5 \\
Stres psikososial kronis & 150 & 35,8 \\
Didapatkan & & 64,2 \\
Tidak didapatkan & 82 & \\
\hline
\end{tabular}

Berdasarkan Tabel 1. diketahui dari 229 responden sebanyak $145(63,3 \%)$ responden dengan usia 35-50 tahun, sebanyak $182(79,4 \%)$ responden dengan jenis kelamin laki-laki, sebanyak 160 (69,8\%) responden dengan pendidikan SMA dan sebanyak $229(100,0 \%)$ responden. Responden dengan hipertensi, sebanyak 79 $(34,5 \%)$ responden yang hipertensi dan sebanyak $150(65,5 \%)$ responden yang tidak hipertensi. Responden dengan stres psikososial kronis , sebanyak $82(35,8 \%)$ responden yang stres psikososial kronis dan sebanyak $147(64,2 \%)$ responden yang tidak stres psikososial kronis .

Rahma Elliya' Program Studi llmu Keperawatan Universitas Malahayati Bandar Lampung.

Email: bundaauliyusri@yahoo.co.id

Marliyana² Akademi Keperawatan Baitul Hikmah Bandar Lampung. Email: marliyana.nafa@yahoo.com

Yulianto $^{3}$ Medical Clinic PT. Indolampung Perkasa Kabupaten Tulang Bawang. *Email: alhusam3012@gmail.com 
Holistik Jurnal Kesehatan, Volume 14, No.1, Maret 2020: 46-51

Stres psikososial kronis dengan kejadian hipertensi pada pekerja lapangan pabrik gula PT. Indolampung Perkasa

Tabel 2. Hubungan Stres Psikososial Kronis Dengan Kejadian Hipertensi $\mathbf{N}=229$

\begin{tabular}{|c|c|c|c|c|c|c|c|c|}
\hline \multirow{3}{*}{$\begin{array}{l}\text { Stres Psikososial } \\
\text { Kronis }\end{array}$} & \multicolumn{4}{|c|}{ Hipertensi } & \multirow{2}{*}{\multicolumn{2}{|c|}{ Total }} & \multirow{3}{*}{$p$-value } & \multirow{3}{*}{ OR } \\
\hline & \multicolumn{2}{|c|}{ Menderita } & \multicolumn{2}{|c|}{ Tidak Menderita } & & & & \\
\hline & $\mathrm{n}$ & $\%$ & $\mathrm{n}$ & $\%$ & $\mathbf{N}$ & $\%$ & & \\
\hline Didapatkan & 40 & 17,5 & 42 & 18,3 & 82 & 35,8 & & 2,637 \\
\hline Tidak didapatkan & 39 & 17,0 & 108 & 47,2 & 147 & 64,2 & 0,001 & $(1496-4650)$ \\
\hline Total & 79 & 34,5 & 150 & 65,5 & 229 & 100,0 & & $(1,496-4,650)$ \\
\hline
\end{tabular}

Berdasarkan tabel 2. diketahui dari 82 responden yang stres psikososial kronis, sebanyak $40(17,5 \%)$ responden hipertensi dan sebanyak 42 $(18,3 \%)$ responden tidak hipertensi. Dari 147 responden yang tidak stres psikososial kronis, sebanyak $39(17,0 \%)$ responden tidak hipertensi dan sebanyak $108(47,2 \%)$ responden hipertensi. Hasil uji statistik diperoleh $p$-value $=0,001$ yang berarti $<a$, maka dapat disimpulkan bahwa ada hubungan stres psikososial kronis dengan kejadian hipertensi, dengan nilai OR 2,637 berarti responden yang stres psikososial kronis memiliki risiko 2,6 kali lebih besar terjadi hipertensi jika dibandingkan dengan responden yang tidak stres psikososial kronis.

\section{PEMBAHASAN \\ Hipertensi}

Berdasarkan hasil penelitian diketahui dari 229 responden dengan hipertensi, sebanyak 79 $(34,5 \%)$ responden yang hipertensi dan sebanyak $150(65,5 \%)$ responden yang tidak hipertensi. Hipertensi dimana keadaan seseorang mengalami peningkatan tekanan darah di atas normal, yaitu tekanan darah sistolik $\geq 140 \mathrm{mmHg}$ dan atau tekanan darah diastolik $\geq 90 \mathrm{mmHg}$ (Price, \& Wilson, 2012; Nadya, 2015). Meningkatnya kejadian hipertensi cenderung terjadi pada orang dengan faktor risiko, hipertensi mempunyai gejala umum yang di timbulkan seperti pusing, palpitasi, mudah lelah, impotensi, sakit kepala, rasa berat ditengkuk, sukar tidur, mata berkunang-kunang (Harrison, Wilson, \& Kasper, 2012). Penyakit hipertensi juga berhubungan dengan pekerjaan yang bersifat multifaktorial, sering kali saling terkait ditempat kerja (Rusnoto, \& Hermawan, 2018).

Faktor-faktor yang menyebabkan terjadinya hipertensi secara umum yaitu toksin, faktor genetik, umur, jenis kelamin, etnis, stres, kegemukan, nutrisi, merokok, narkoba, alkohol, kafein, kurang berolahraga dan kolesterol tinggi
(Susilo, \& Wulandari, 2011; Sulastri, Elmatris, \& Ramadhani, 2012; Fitrina, 2014).

Penelitian sebelumnya menunjukkan bahwa responden yang paling banyak dengan lama menderita hipertensi yang paling banyak 1-3 tahun dan 3-5 tahun yang masing-masing sebanyak 13 orang $(40,6 \%)$ dan yang paling sedikit dengan lama menderita hipertensi $<1$ tahun sebanyak 2 orang $(6,3 \%)$ dari 32 responden (Suoth, Bidjuni, \& Malara, 2014).

\section{Stres psikososial kronis}

Berdasarkan hasil penelitian, diketahui dari 229 responden dengan stres psikososial kronis, sebanyak $82(35,8 \%)$ responden yang stres psikososial kronis dan sebanyak $147(64,2 \%)$ responden yang tidak stres psikososial kronis . Stres dialami karena respon tubuh yang sifatnya nonspesifik terhadap setiap tuntutan beban atasnya. Bila seseorang setelah mengalami stres mengalami gangguan pada satu atau lebih organ tubuh sehingga yang bersangkutan tidak lagi dapat menjalankan fungsi pekerjaannya dengan baik, maka disebut mengalami distres (Hawari, 2013).

Stres menimbulkan stimulus dan menciptakan tuntutan fisik dan psikis pada seseorang. Stres membutuhkan koping dan adaptasi, stres sebagai kerusakan yang terjadi pada tubuh tanpa mempedulikan apakah penyebab stres tersebut positif atau negatif. Respons tubuh dapat diprediksi tanpa memerhatikan stresor atau penyebab tertentu (Mumpuni, 2010; Indah, 2015).

Lingkungan kerja dengan kondisi yang buruk berpotensi menjadi penyebab karyawan mudah jatuh sakit, mudah stres, sulit berkonsentrasi dan menurunnya produktivitas kerja. Bayangkan saja, jika ruangan kerja tidak nyaman, panas, sirkulasi udara kurang memadai, ruangan kerja terlalu pada, lingkungan kerja kurang bersih, berisik, tentu besar pengaruhnya pada kenyamanan kerja karyawan (Ibrahim, Amansyah, \& Yahya, 2016).

Rahma Elliya' Program Studi llmu Keperawatan Universitas Malahayati Bandar Lampung.

Email: bundaauliyusri@yahoo.co.id

Marliyana $^{2}$ Akademi Keperawatan Baitul Hikmah Bandar Lampung. Email: marliyana.nafa@yahoo.com

Yulianto ${ }^{3}$ Medical Clinic PT. Indolampung Perkasa Kabupaten Tulang Bawang. *Email: alhusam3012@gmail.com 
Stres psikososial kronis dengan kejadian hipertensi pada pekerja lapangan pabrik gula PT. Indolampung Perkasa

\section{Hubungan Tingkat Stres Dengan Kejadian Hipertensi}

Hasil uji statistik diperoleh $p$-value $=0,001$ yang berarti $<a$, maka dapat disimpulkan bahwa ada tingkat stres dengan kejadian hipertensi pada pekerja lapangan dengan nilai OR 2,637 berarti responden yang stres memiliki risiko 2,6 kali lebih besar terjadi hipertensi jika dibandingkan dengan responden yang tidak stres.

Stres dialami karena respon tubuh yang sifatnya nonspesifik terhadap setiap tuntutan beban. Bila seseorang setelah mengalami stres mengalami gangguan pada satu atau lebih organ tubuh sehingga yang bersangkutan tidak lagi dapat menjalankan fungsi pekerjaannya dengan baik, maka disebut mengalami distres (Hawari, 2013).

Berdasarkan hasil penelitian diketahui dari 82 responden yang stres, sebanyak $42(18,3 \%)$ responden tidak hipertensi hal ini dimungkinkan karena setiap orang berbeda dalam penanganan stress, ada yang dapat menanggulangi secara langsung dari stres yang dihadapi namun ada pula yang tidak dapat mengontrol diri saat sedang stres. Dari 147 responden yang tidak stres psikososial kronis sebanyak $108 \quad(47,2 \%)$ responden hipertensi.

Menurut pendapat peneliti hal ini dimungkinkan adanya faktor lain yang menyebabkan hipertensi sehingga walaupun responden termasuk dalam kelompok tidak stres psikososial kronis namun responden mengalami hipertensi seperti kemungkinan responden merupakan kelompok obesitas, atau adanya faktor lain yang tidak diambil dalam penelitian ini seperti gaya hidup yang lain, antara lain merokok, konsumsi asupan garam tinggi, adanya keturunan sehingga responden mengalami hipertensi.

\section{SIMPULAN}

Diketahui dari 229 responden dengan hipertensi sebanyak 79 responden $(34,5 \%)$ dan sebanyak 150 responden $(65,5 \%)$ yang tidak hipertensi. Diketahui dari 229 responden dengan stres psikososial kronis, sebanyak 82 responden $(35,8 \%)$ dan sebanyak 147 responden $(64,2 \%)$ yang tidak stres psikososial kronis . Ada hubungan tingkat stres dengan kejadian hipertensi pada pekerja lapangan ( $p$-value 0,$001 ;$ OR 2,637).

\section{SARAN}

Peneliti selanjutnya diharapkan dapat melakukan penelitian yang lebih lengkap dan menggali informasi yang lebih dalam serta memperhatikan faktor lain yang berhubungan dengan hipertensi pada pekerja lapangan dan faktor stress yang terjadi dengan metode penelitian yang lebih mendalam yaitu penelitian kualitatif.

\section{DAFTAR PUSTAKA}

Andria, K. M. (2013). Hubungan antara perilaku olahraga, stres dan pola makan dengan tingkat hipertensi pada lanjut usia di Posyandu Lansia Kelurahan Gebang Putih Kecamatan Sukolilo Kota Surabaya. Jurnal Promkes, 1(2), 111-117.

Arifin, M. H. B. M., \& Weta, I. W. (2016). Faktorfaktor yang berhubungan dengan kejadian hipertensi pada kelompok lanjut usia di wilayah kerja UPT Puskesmas Petang I Kabupaten Badung tahun 2016. E-Jurnal Medika Udayana, 5(7).

Dinas Kesehatan Tulang Bawang. (2017). Profil kesehatan Tulang Bawang tahun 2016. Provinsi Lampung.

Fitrina, Y. (2014). Faktor-Faktor Yang Berhubungan Dengan Kejadian Hipertensi Pada Usia Lanjut Di Wilayah Kerja Puskesmas Kebun Sikolos Kecamatan Padang Panjang Barat Tahun 2014. 'Afiyah, 1(2).

Harrison, I., Wilson, B. W., \& Kasper, M. F. (2012). Prinsip-prinsip ilmu penyakit dalam, edisi 13. Jakarta: EGC.

Hawari, D. (2013). Cemas dan Depresi. Jakarta: FKUI (Fakultas Kedokteran Universitas Indonesia).

Ibrahim, H., Amansyah, M., \& Yahya, G. N. (2016). Faktor-Faktor yang Berhubungan Dengan Stres Kerja Pada Pekerja Factory 2 PT. Maruki Internasional Indonesia Makassar Tahun 2016. Al-sihah: The Public Health Science Journal, 8(1).

Rahma Elliya' Program Studi llmu Keperawatan Universitas Malahayati Bandar Lampung.

Email: bundaauliyusri@yahoo.co.id

Marliyana ${ }^{2}$ Akademi Keperawatan Baitul Hikmah Bandar Lampung. Email: marliyana.nafa@yahoo.com

Yulianto ${ }^{3}$ Medical Clinic PT. Indolampung Perkasa Kabupaten Tulang Bawang. *Email: alhusam3012@gmail.com 
Stres psikososial kronis dengan kejadian hipertensi pada pekerja lapangan pabrik gula PT. Indolampung Perkasa

Indah, I, K. (2015). Hubungan antara Stres dengan Hipertensi pada Pasien Rawat Jalan di Puskesmas Rapak Mahang Kabupaten Kutai Kartanegara Provinsi Kalimantan Timur (Doctoral dissertation, Universitas Muhammadiyah Surakarta).

Kementerian Kesehatan Republik Indonesia. (2014). Infodatin Hipertensi. Jakarta: Pusat Data dan Informasi Kementerian Kesehatan Republik Indonesia.

Kementerian Kesehatan Republik Indonesia. (2017). pusat data dan informasi Profil Kesehatan Indonesia 2016. Kementerian Kesehatan RI, Jakarta.

Kementerian Kesehatan Republik Indonesia. (2018). Hasil Utama Riskesdas 2018. Kemenkes Balitbangkes.

Mumpuni, Y., \& Wulandari, A. (2010). Cara Jitu Mengatasi Stres. Yogyakarta. Andi Offset.

Nadya, W. N. (2015). Hubungan Stres Kerja Dengan Kejadian Hipertensi Pada Karyawan PT. Kencana Sawit Indonesia Solok Selatan (Doctoral dissertation, UPT. Perpustakaan Unand).
Price, S. A., \& Wilson, L. M. (2012). Patofisiologi konsep klinis proses-proses penyakit. Jakarta: EGC.

Rusnoto, R., \& Hermawan, H. (2018). Hubungan Stres Kerja Dengan Kejadian Hipertensi Pada Pekerja Pabrik Di Wilayah Kerja Puskesmas Kaliwungu. Jurnal IImu Keperawatan dan Kebidanan, 9(2), 111-117.

Sari, Y.N. (2017). Berdamai Dengan Hipertensi. Jakarta: Bumi Medika.

Sulastri, D., Elmatris, E., \& Ramadhani, R. (2012). Hubungan obesitas dengan kejadian hipertensi pada masyarakat etnik minangkabau di kota padang. Majalah Kedokteran Andalas, 36(2), 188-201.

Suoth, M., Bidjuni, H., \& Malara, R. (2014). Hubungan gaya hidup dengan kejadian hipertensi di puskesmas kolongan kecamatan kalawat kabupaten minahasa utara. Jurnal Keperawatan, 2(1).

Susilo, Y., \& Wulandari, A. (2011). Cara jitu mengatasi hipertensi. Yogyakarta: Andi.

Syavardie, Y. (2015). Pengaruh Stres Terhadap Kejadian Hipertensi di Puskesmas Matur, Kabupaten Agam. 'Afiyah, 2(1).

Rahma Elliya' Program Studi llmu Keperawatan Universitas Malahayati Bandar Lampung.

Email: bundaauliyusri@yahoo.co.id

Marliyana ${ }^{2}$ Akademi Keperawatan Baitul Hikmah Bandar Lampung. Email: marliyana.nafa@yahoo.com

Yulianto ${ }^{3}$ Medical Clinic PT. Indolampung Perkasa Kabupaten Tulang Bawang. *Email: alhusam3012@gmail.com 